\title{
TEKSTUALITAS VIS-À-VIS KONTEKSTUALITAS (Studi Kritis Penafsiran Ayat-Ayat Politik Muhammad Asad [1900-1992])
}

\author{
Zaimul Asroor \\ Pascasarjana UIN Syarif Hidayatullah Jakarta \\ asroraim7@gmail.com
}

Diterima 22 Oktober 2019 | Direview 25 Desember 2019 | Diterbitkan 30 Desember 2019

\begin{abstract}
:
Muhammad Asad, one of the interpreters in the modern age from the West, is known as a figure whose views are quite progressive and contextual. However, there is little research that shows that in some of cases-Asad's views also tend to be textual. This paper wants to show where the textuality and contextual interpretations of Mubammad Asad are, especially in some Islamic political matters. For instance, issues of Democracy and Shura, non-Muslim leaders and Jinayat Law. To analyze the above problems, the writer uses primary data in the form of his interpretation of The Message of the Qur'an and The Principle of State and Government in Islam. The method that the writer use is a comparative method with historical analysis and textual-contextual approach initiated by Abdullah Saeed
\end{abstract}

Keywords: Muhammad Asad, Political Verses, Textual-contextual

\begin{abstract}
Abstrak:
Muhammad Asad, salah satu mufasir Abad modern dari Barat, dikenal sebagai tokoh yang pandangannya cukup progresif dan kontekstual. Namun, kiranya masih sedikit penelitian yang menunjuk.kan bahwa dalam beberapa halpandangan Asad juga cenderung tekstual. Tulisan ini ingin menunjukekan di mana sisi tekstualitas dan kontekstualitas penafsiran Mubammad Asad, khususnya dalam beberapa persoalan politik Islam. Misalnya, persoalan Demokrasi dan Syura, Pemimpin non-Muslim dan Hukum Jinayat. Untuk menganalisis persoalan di atas, penulis menggunakan data primer berupa karya tafsirnya The Message of The Qur'an dan The Principle of State and Government in Islam. Adapun metode yang penulis gunakan adalah metode komparasi dengan analisis historis dan pendekatan tekstual-kontekstual yang digagas oleh Abdullah Saeed.
\end{abstract}

Kata Kunci: Muhammad Asad, Ayat-ayat Politik, Tekstual-kontekstual

\section{Pendahuluan}

Sebuah penafsiran atas al-Qur'an merupakan sebuah upaya untuk menjelaskan isi atau kandungan nilai-nilai al-Qur'an yang bisa diaplikasikan dalam kehidupan nyata, khususnya bagi umat Islam. Karena penafsiran bukanlah karya Tuhan, melainkan karya manusia, maka sebuah perbedaan pasti akan timbul. Tafsir al-Qur'an juga akan terus diuji oleh perkembangan zaman. Karena bagaimanapun, penafsiran yang tidak dapat "berkomunikasi" dengan konteks yang melingkupinya akan dianggap usang, bahkan bisa disisihkan. Di sinilah letak pentingnya seorang mufasir yang diharapkan mampu untuk mengerti apa yang sedang dibutuhkan oleh zamannya.

Muhammad Asad adalah salah satu mufasir yang fokus kajiannya tidak jauh dari alQur'an. Ia menghabiskan waktu kurang lebih selama 17 tahun untuk menyelesaikan masterpiece nya ini. Banyak yang memandang bahwa Asad adalah tokoh progresif, moderat bahkan liberal. Argumentasi ini didasari oleh beberapa pandangan Asad-baik dalam tafsirnya The Message atau karyanya yang lain-yang kiranya dianggap melenceng dari kebanyakan pendapat ulama'. Memang dalam beberapa kasus hal ini boleh jadi demikian, namun dalam beberapa kasus yang lain (semisal pandangannya tentang politik Islam) masih sedikit yang menyadari bahwa Asad pun sebenarnya juga bagian dari seseorang yang terkadang masih terkungkung pada pandangan ulama terdahulu (tekstualis). Di mana sisi tekstualitas maupun kontekstualitas Asad? tulisan ini akan menjawabnya. 



\section{Metode Penelitian}

Sebagaimana disebutkan sekilas di dalam abstrak, bahwa tulisan ini merupakan kajian tokoh. Maka dalam pembahasannya akan ditekankan pada satu tokoh saja, yakni Muhammad Asad. Akan tetapi, hal ini tidak menutup kemungkinan adanya berbagai pandangan lain untuk menganalisa dan memperkaya isi tulisan. Adapun metode yang penulis gunakan adalah: pertama, metode komparasi, khususnya untuk mengkomparasikan karya Asad The Principle of State and Government in Islam dan tafsir The Message of The Qur'an, kedua, metode historis. Metode historis sendiri penulis gunakan untuk merangkai berbagai kronologi kehidupan Asad supaya terlihat apakah ada perubahan sikap dari dalam dirinya dari masa ke masa atau tidak. Selain itu, untuk melihat sisi tekstual-kontekstual dari penafsiran Asad, penulis menggunakan pendekatan tekstual dan kontekstual yang digagas oleh Abdullah Saeed.

\section{Diskursus Pendekatan Penafsiran}

Dalam tradisi penafsiran al-Qur'an, ${ }^{1}$ jumhur ulama' yang menekuni kajian 'ulum al-Qur'an seperti al-Zarqani, al-Qattan dan Subhi Salih mengklasifikasikan bentuk utama penafsiran al-Qur'an menjadi dua, yakni bi al-Ma'tsur dan bi al-Ra'yi. ${ }^{2}$ Selain dua klasifikasi utama tersebut, terdapat juga satu bentuk lain penafsiran klasik di kala itu, yakni tafsir Isyari (penafsiran yang lebih menitik beratkan aspek batin atau ruhani). ${ }^{3} \quad$ Klasifikasi bentuk atau model penafsiran klasik ini selanjutnya dikembangkan lagi di masa modern. Tokoh seperti Abdul Hayy al-Farmawi menjadi salah satu "pendahulunya". Dalam klasifikasi Farmawi, terdapat empat metode (manhaj) penafsiran yang selama ini digunakan para mufasir baik di era klasik, pertengahan maupun modern: Tablili, Ijmali, Muqaran dan Maudu'i. Pengelompokan metode ini selanjutnya diikuti oleh tokoh-tokoh belakangan, sebut saja tokoh-tokoh

${ }^{1}$ Orang pertama yang menafsirkan al-Qur'an adalah Nabi Muhammad SAW (w.11 H/632 M). Setelah beliau wafat, dua elemen penting yang mendasari pemahaman al-Qur'an sudah tidak ada lagi, yakni kehadiran Nabi dan keseluruhan konteksnya (secara politik, ekonomi, sosial, kultural dan intelektual) di mana al-Qur'an diturunkan saat itu. Setelah itu, penafsiran dilanjutkan oleh beberapa sahabat dengan cara menggunakan beragam sumber. Diantara pendekatan yang mereka gunakan adalah menggunakan ayat-ayat al-Qur'an untuk menjelaskan maksud ayat-ayat yang lain, menghimpun hadist Nabi, bahkan mengumpulkan tradisi-tradisi Ahli Kitab (Yahudi dan Kristen). Setelah era sahabat telah rampung, tonggak penafsiran diberikan kepada para tabiin (generasi kedua umat Islam), tabi'it tabi'in dan beberapa ulama' setelahnya. Untuk melihat perkembangan pemahaman atas al-Qur'an, bisa dilihat beberapa kitab Ulum al-Qur'an seperti Manabil al-Trfan. Lihat Muhammad Abdul 'Adzim al-Zarqani, Manabil al-Irfan (Kairo: Dar al-Salam, 2015), cetakan ke 4, 381.

${ }^{2}$ al-Ma'thur dan al-Ra'yi juga bisa dikategorikan dalam sumber penafsiran. Nama lain dari keduanya adalah bi al-Riwayah dan bi al-Dirayah. Lihat al-Zarqani, Manahil al-Irfan, (Kairo: Dar al-Salam, 2015), cetakan ke 4, 387, 415. Manna' Khalil Qattan, Mababith fi Ulum al-Qur'an (Kairo: Maktabah Wahbah, tt), 337. Subhi Salih, Mababith fi 'Ulum al-Qur'an (Beirut: Dar al'ilmi li al-Malayin, 1977), 291.

3Biasanya mufasir-mufasir yang masuk dalam kategori ini adalah mereka yang lebih melakukan pendekatan kesufian. Seperti Tafsir al-Alusi oleh Imam al-Alusi (w. $1270 \mathrm{H}$ ). Lihat Salih, Mabahith fi 'Ulum al-Qur'an, (Beirut: Dar al-'ilmi li al-Malayin, 1977), 296.

${ }^{4}$ Dalam kitabnya ini, al-Farmawi memasukkan metode tafsir bi al-Ma'thur, bi al-Ra'yi dan Isyari kedalam kategori Tablili. Lihat Abdul Hayy al-Farmawi, al-Bidayah fi al-Tafsir alMaudu'i: Dirasah Manhajizah Maudu'iyah. t.tp. tp. 
Indonesia seperti Quraish Shihab. ${ }^{5}$ Namun memang terkadang perbedaan penyebutan antara metode dan pendekatan penafsiran seringkali tumpang tindih. Hal inilah yang kemudian membuat Islah Gusmian-dalam bukunya Khazanah Tafsir Indonesia-ikut berkomentar dan mencoba mengelaborasi perbedaan dasar antara istilah-istilah di atas. ${ }^{6}$

Dari klasifikasi metode atau pendekatan yang telah disebutkan di atas, terdapat satu persamaan utama dari semua penafsiran yang ada, yakni begitu mendominasinya aspek kebahasaan. Sebagai contoh, Tafsir karya Shihab al-Din al-Khaffaji (1659), alBaidhawi (1286) hingga sekarang masih dipergunakan di pesantren-pesantren. Tanpa harus mengecilkan jasa besar tafsir yang bercorak leksiografis di atas, corak penafsiran seperti itu-menurut Amin Abdullah-akan membawa kita pada pemahaman yang kurang utuh. Sebagai contoh, karya tafsir yang menonjolkan aspek ijaz akan membuat kita terpesona dengan keindahan bahasa al-Qur'an, akan tetapi belum dapat menguak nilai-nilai spiritual dan sosio-moral al-Qur'an untuk kehidupan sehari-hari manusia. ${ }^{7} \quad$ Begitu juga dengan beberapa pendekatan yang lainnya. Bila terlalu menonjolkan salah satu aspek saja tanpa dielaborasi dengan pendekatan yang lain, kemungkinan besar akan membawa pada kesimpulan yang sama.

Perkembangan di era kontemporer seperti sekarang-dengan segala persoalan dan tantangannya-juga membuat para pengkaji al-Qur'an semakin memberikan perhatian penuh atas ayat-ayat maupun penafsiran al-Qur'an yang kiranya dianggap oleh sebagian dari mereka terkesan "bungkam" bahkan tidak mampu berbuat banyak. Bila anggapan ini diyakini kebenarannya, lalu di mana letak universalitas al-Qur'an yang dianggap mampu menjawab berbagai persoalan dari masa ke masa?

Menanggapi pertanyaan yang terkesan meragukan di atas lah akhirnya membuat para sarjana peminat kajian al-Qur'an mengajukan gagasannya. Salah satunya adalah Abdullah Saeed. Menurutnya, ada dua kecenderungan utama dalam penafsiran alQur'an; tekstual dan kontekstual. Kelompok tekstual (textualists) berkeyakinan bahwa al-Qur'an lah yang harus selalu menjadi pegangan umat Islam, melebihi apa yang kemudian disebut sebagai kebutuhan modern (modern needs). ${ }^{8}$ Apa yang diinginkan Saeed bukan berarti "menggeser" posisi al-Qur'an, akan tetapi ia mengkritisi bahwa kebanyakan ulama' ketika terlalu menekankan aspek bahasa atau teks al-Qur'an, tidak sedikit yang meyakini bahwa itulah pemahaman yang harus diaplikasikan untuk setiap generasi-sampai kapanpun. Pendekatan ini (tekstual) telah menjadi pendekatan utama dalam tafsir, khususnya yang berkaitan dengan ayat-ayat hukum/etika (ethico-legal), dan dalam literatur fikih.' Sebagai contoh, jika al-Qur'an mengatakan bahwa laki-laki dapat menikahi empat perempuan berarti pemahaman ini harus tetap diterapkan sampai kapanpun, tanpa harus mempertimbangkan bagaimana konteks sosio-historis teks tersebut saat pertama kali diwahyukan. Pertanyaan mengapa al-Qur'an

${ }^{5}$ Quraish Shihab, Kaidah Tafsir (Tangerang: Lentera Hati, 2015), 377.

'Islah Gusmian, Khazanah Tafsir Indonesia: Dari Hermeneutika hingga Ideologi (Yogyakarta: LkiS, 2013), 111-119.

${ }^{7}$ Amin Abdullah, Studi Agama: Normativitas atau Historisitas? (Yogyakarta: Pustaka Pelajar, 2015), cet: IV, 139.

${ }^{8}$ Abdullah Saeed, Interpreting the Quran: Towards Comtemporary Approach (New York: Routledge, 2006), 3 .

${ }^{9}$ Abdullah Saeed, al-Qur'an Abad 21: Tafsir Kontekstual (terj) dari buku Reading the Qur'an in the Twenty First Century (Bandung: Mizan, 2016), 12. 
membolehkan laki-laki menikahi empat istri di abad pertama/tujuh di Hijaz bukanlah persoalan penting. ${ }^{10}$

Beda halnya dengan kelompok kontekstual, bagi pendukung kelompok ini mereka tidak hanya memperhatikan makna etik dan hukum al-Qur'an, tetapi juga konteks sosio-historis ketika ayat itu diturunkan. Misalnya, satu ayat al-Qur'an dilihat dari konteks politik, ekonomi, sejarah dan budayanya saat pertama kali diturunkan, ditafsirkan dan dipraktekkan. Oleh karena itu, mereka menjunjung tinggi nilai kebebasan (bigh degree of freedom) dan membedakan mana ayat-ayat al-Qur'an yang maknanya tidak dapat berubah dan mana yang dapat berubah. Di antara tokoh yang masuk dalam kategori kontekstualis ini adalah Fazlur Rahman. ${ }^{11}$ Pendekatan yang ditawarkan oleh Saeed ini sebenarnya merupakan pengembangan dari teori Double Movement yang digagas Rahman. ${ }^{12}$ Selanjutnya, dua pendekatan di atas berusaha dikembangkan lagi oleh Sahiron Syamsuddin. Menurutnya, pendekatan kontekstual yang dilakukan baik Rahman maupun Saeed hanya terbatas pada ayat ethico-legal saja. Oleh karena itu, ia memperkenalkan pendekatannya dengan istilah ma'na cum maghza. Baginya, ma'na cum maghza ini bisa digunakan untuk mendekati seluruh ayat alQur'an. ${ }^{13}$

Selanjutnya, ketika kita membandingkan-untuk tidak mengatakan membenturkan-pendekatan tekstual dan kontekstual dalam memahami al-Qur'an, mungkin akan timbul pertanyaan di benak kita, "pendekatan mana yang harus didahulukan? atau apakah semua ayat harus didekati secara kontekstual?". Menanggapi pertanyaan seperti ini, Abdullah Saeed menjelaskan bahwa tidak semua ayat harus dipahami secara kontekstual, maupun sebaliknya, tekstual. Bagi Saeed, ayat yang cukup dipahami secara tekstual misalnya yang terkait dengan aspek historis, teologis dan eskatologis. Sedangkan, ayat yang tidak cukup dipahami secara tekstual adalah ayat-ayat tentang yang berkaitan dengan berbagai situasi yang secara erat berkait dengan saat turunnya ayat. Teks-teks atau ayat inilah yang ia namakan sebagai teks ethico-legal yang menekankan masalah etika, moral, sosial, atau hukum. Misalnya persoalan tentang pernikahan, perceraian, peran laki-laki dan perempuan, status nonMuslim dalam masyarakat Islam, dan lain sebagainya. ${ }^{14}$ Pandangan seperti inilah yang menurut penulis sebagai bentuk kehati-hatian dari ijtihad Saeed dalam mengemukakan pendekatan yang ia tawarkan supaya tidak menjadi pendekatan yang "sembrono" atau tidak berdasar. 2006), 3

${ }^{10}$ Abdullah Saeed, Interpreting the Quran: Towards Comtemporary Approach (New York: Routledge,

${ }^{11}$ Salah satu intelektual muslim Barat yang tertarik untuk membandingkan pemahaman kelompok tekstual dan kontekstual berdasarkan tokoh-tokohnya adalah Adis Duderija dalam karya yang awalnya adalah disertasi, "Constructing a Religiously Ideal "Believer" and "Woman" in Islam: Neo-traditional Salafi and Progressive Muslims' Method of Interpretation”. Diterbitkan di New York oleh Palgrave Macmillan pada tahun 2011.

${ }^{12}$ Fazlur Rahman, Islam and Modernity (Chicago: University of Chicago Press, 1982), h. 5.

13 Sahiron Syamsuddin, “Ma'na Cum Maghza Approach to The Qur'an: Interpretation of Q 5:51," Advances in Social Science, Education and Humanities Research (ASSEHR), Vol. 137, 2017, hal. 131-132. Untuk melihat landasan hermeneutika dari pengembangan pendekatan Sahiron inibegitu juga beberapa aplikasi penafsirannya, silahkan baca Sahiron Syamsuddin, Hermeneutika dan Pengembangan Ulumul Qur'an (Yogyakarta: Pesantren Nawesea Press, 2009), 73.

${ }^{14}$ Abdullah Saeed, al-Qur'an Abad 21: Tafsir Kontekstual (terj) dari buku Reading the Qur'an in the Twenty First Century (Bandung: Mizan, 2016), 15. 
Terlepas dari perbedaan cara memahami al-Qur'an di atas, satu hal yang perlu dicatat bahwa berbagai upaya yang telah dikerahkan oleh para sarjana al-Qur'an di atas merupakan hal yang sangat wajar dan sah-sah saja selama tidak melewati ramburambu akidah maupun ibadah yang sifatnya telah disepakati oleh jumhur ulama'. Di sisi lain, upaya untuk memahami al-Qur'an yang universal itu akan terus berlangsung dan tidak akan pernah ada kata final. Jadi, bisa saja pendekatan maupun penafsiran yang diyakini efektif dan diyakini kebenarannya di era sekarang, belum tentu dapat menjawab persoalan-persoalan di masa mendatang. ${ }^{15}$

\section{Perdebatan Ayat-ayat Politik}

Setelah melihat sekilas tentang perdebatan pendekatan maupun metode dalam memahami pesan Tuhan (al-Qur'an), kiranya perlu diungkapkan di sini apa pentingnya pembahasan tentang ayat-ayat politik. Menurut penulis, pembahasan ini sangat relevan dengan pembahasan sebelumnya. Karena bagaimanapun, apapun pembahasan dan kajiannya bila masih terkait dengan sebuah ayat al-Qur'an, maka tidak akan bisa dipungkiri bahwa peran pemahaman dan penafsiran akan muncul di situ. Dan pendekatan yang digunakan untuk memahami sebuah ayat inilah yang akan menentukan kesimpulan yang diambil oleh sang mufasir, dalam konteks ini adalah pemahaman atas ayat-ayat politik.

Sebelum menjelaskan apa yang dimaksud penulis dengan ayat-ayat politik, penting juga diulas secara singkat pengertian politik. Istilah politik sendiri pertama kali dijelaskan oleh filsuf Yunani kuno, Plato dan Aristoteles. Keduanya memaknai politik atau Polis (dalam bahasa Yunani) sebagai usaha untuk mencapai masyarakat politik (polity) yang terbaik (good life). Pengertian demikian bertahan kiranya sampai abad ke-19. Karena setelah era itu, pengertian politik lebih ditekankan pada upaya (means) untuk mencapai masyarakat baik. Misalnya kekuasaan, pembuatan keputusan, kebijakan, alokasi nilai dan sebagainya. Menurut Peter Merkl, politik dalam bentuk paling baik adalah usaha mencapai tatanan sosial yang baik dan berkeadilan. ${ }^{16}$

Dari pengertian-pengertian yang telah ada sebelumnya, Miriam Budiarjo menyimpulkan bahwa konsep-konsep pokok politik mencakup: negara, kekuasaan, pengambilan keputusan, kebijakan dan pembagian (distribution) atau alokasi. ${ }^{17}$ Jadi dapat dipahami bahwa ketika membicarakan politik, maka kita tidak akan pernah lepas dari unsur-unsur seperti: negara, kekuasaan dan juga rakyat. Jika demikian, dalam kaitannya dengan Islam, apakah Islam juga mengurusi persoalan politik? pertanyaan seperti ini pernah coba dijawab oleh Cak Nur. Ia mengatakan bahwa mengingkari hubungan politik dan agama (politik Islam) berarti mengingkari realitas sejarah Islam yang sudah berlangsung lebih dari 14 abad lamanya. Lebih dari itu, mengingkarinya juga berarti mengingkari salah satu bagian esensial Islam. ${ }^{18}$

Agar lebih jelas bagaimana hubungan Islam dan politik (politik Islam), terlebih dahulu penulis ingin mengemukakan pengertian politik Islam. Politik Islam dapat diartikan mulai dari bentuk partai politik, mengagendakan Islam sebagai panduan

${ }^{15} \mathrm{Al}-$ Hakim, Al-Mustadrak 'ala al-Sabihain., 11-12.

${ }^{16}$ Peter H. Merkl, Continuity and Change (New York: Harper and Row, 1967), 13.

${ }^{17}$ Miriam Budiarjo, Dasar-dasar Ilmu Politik (Jakarta: Gramedia Pustaka, 2018), edisi revisi cetakan ke-3, 13-17.

${ }^{18}$ Kata Pengantar Nurcholis Madjid dalam buku Munawwir Syadzali, Islam and Governmental System (Jakarta: Indonesian-Netherlands Cooperation in Islamic Studies, 1991), xv. 
utama (guiding principle), bahkan blue print dalam sebuah pemerintahan, ${ }^{19}$ sampai kepada penggunaan Islam untuk kepentingan pribadi, politik partai dan kelompok. ${ }^{20}$ Dari luasnya cakupan yang terdapat dalam pengertian politik Islam inilah akhirnya beberapa isu penting dalam politik Islam pun muncul. Misalnya, tentang persoalan konsep kedaulatan Tuhan, ulil amri, musyawarah (Syura), hubungan muslim dengan non-muslim serta pengangkatan non-muslim sebagai pemimpin, posisi perempuan di ranah publik (negara) dan implementasi hukum syariah (hukum pidana Islam) dalam sebuah negara; potong tangan dan rajam, $\mathrm{dll}^{21}$

Perdebatan yang masuk dalam ranah politik Islam-selain karena kondisi bangsa muslim yang "kalah"-bisa dikatakan bermula pada satu hal, yakni penafsiran atas ayatayat al-Qur'an. Memang begitu banyak ayat al-Qur'an yang dijadikan landasan atas sebuah gagasan. Tidak ada yang salah dalam pemahaman demikian, karena sebagai seorang muslim tentu memahami al-Qur'an sebagai guidance adalah sebuah keharusan. Yang menjadi soal adalah apabila pemahaman yang dianggap benar itu kemudian menyalahkan bahkan menyesatkan pemahaman lain yang berbeda, dan inilah yang sering terjadi di lapangan (termasuk dalam memahami ayat-ayat politik). Sebagai contoh, bagaimana kemudian perdebatan tentang landasan sebuah negara mengemuka. Sebagian muslim meyakini bahwa mereka akan berdosa bila tidak mewujudkan negara Islam. ${ }^{22}$ Mereka berlandaskan atas sebuah ayat dalam surat alNahl :89:

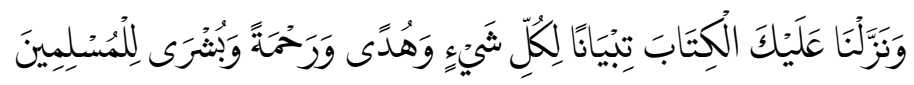

Ayat di atas dijadikan landasan mereka dalam meyakini bahwa Islam tidak mengakui antara pemisahan agama dan negara, karena ia telah menjelaskan segala hal (tibyanan likulli syai'in). Maka dari itu, istilah al-Islam din wa al-Daulah adalah hal yang wajar bagi mereka. ${ }^{23}$ Abdurrahman Wahid atau akrab disapa Gusdur pun ikut berkomentar, bahwa ayat lain yang menyebabkan mereka berpandangan tentang kewajiban mendirikan negara Islam bersumber dari pemaknaan ayat yang berbunyi udkhulu fi al-silmi kaffah. Mereka memaknai kata al-silm dengan Islam, sedangkan kelompok lain yang lebih menekankan aspek substansi ajaran Islam menafsirkan kata al-silm dengan sifat kedamaian sehingga tidak perlu bentuk formal. Terlebih, ayat lain yang cukup populer dalam melegitimasi pendirian negara Islam juga sering muncul dalam perdebatan politik Islam. ayat itu berbunyi wa man lam yabkum bima anzalallabu fa'ulaika humul kafirun. Kiranya tepat bila akhirnya Gusdur menilai kelompok formalistik di atas sangat ahistoris dan atomistic, karena ayat tersebut konteksnya adalah ditujukan kepada orang Yahudi dan Nasrani, bukan kepada orang Islam. ${ }^{24}$

Apa implikasinya bila pemahaman Islam formal seperti yang telah disebutkan diterapkan dalam ranah yang sifatnya lebih partikular? Jelas, imbas dari pemahaman

\footnotetext{
${ }^{19}$ Shahram Akbarzadeh dan Abdullah Saeed (ed), Islam and Political Legitimacy (New York: Routledge Curzon, 2003), 2.

${ }^{20}$ Delmus Puneri Salim, "Politik Islam dalam al-Qur'an: Tafsir Siyasah Surat Ali Imran Ayat 159" Jurnal Aqlam; Journal of Islam and Plurality, Vol. 1, No. 1 (2016), 43.

${ }^{21}$ Sukron Kamil, Syari'ab Islam dan HAM (Jakarta: CSRC, 2007), 207.

${ }^{22}$ Abdul Aziz, Chiefdom Madinab: Salah Paham Negara Islam (Jakarta: Pustaka Alvabet, 2011), 1.

${ }^{23}$ Bahtiar Effendi, Islam dan Negara: Transformasi Gagasan dan Praktik Politik Islam di Indonesia (Jakarta: Democracy Project, edisi Digital, 2011), 209.

${ }^{24}$ Abdurrahman Wahid, Islamku Islam Anda Islam Kita (Jakarta: The Wahid Institute, 2006), 3.
} 
akan kewajiban mendirikan negara Islam adalah penerapan aturan-aturan Islam yang terkesan dipaksakan dalam sebuah negara. Misalnya saja penerapan hukum pidana Islam (jinayah), seperti hukum potong tangan, rajam maupun cambuk. Bagi mereka, hukum pidana Islam tidaklah seperti hukum modern. Hukum modern merupakan buatan manusia, sedangkan hukum pidana Islam yang membuat adalah Allah. ${ }^{25}$ Selain itu, imbas lain dari pandangan maupun penafsiran formalistik dan tekstualis juga tercermin dalam persoalan seperti hak non-muslim yang sering dikebiri dan menjadi warga kelas dua. Misalnya saja, Ibnu 'Ashur sebagai tokoh modern dan pengusung Maqasid al-Shariah ternyata juga tetap berpandangan tekstualis dengan melarang nonMuslim menjadi pemimpin, ${ }^{26}$ bagaimanapun kondisinya. Ia mendasari pemahaman penafsirannya itu dengan QS al-Maidah (5): 51.

Melihat fenomena dunia muslim yang sedang "kalah" di kala itu, kemudian juga munculnya perdebatan dikarenakan perbedaan penafsiran atas ayat-ayat politik itulah yang akhirnya membuat sarjana muslim kontemporer seperti Muhammad Asad ikut berkomentar dan menyuarakan gagasannya. Melalui kajian pustaka yang penulis lakukan, ternyata pandangan beberapa tokoh ketika menilai Asad sebagai tokoh modern bahkan liberal dalam menafsirkan ayat al-Qur'an tidaklah selamanya tepat. Karena ternyata, dalam beberapa hal khususnya yang berkaitan dengan penafsiran ayat-ayat politik, penulis menemukan "sisi lain" Asad yang terkadang juga masih kukuh mengikuti pandangan tekstualis. Inilah yang menjadi pembahasan inti penulis nantinya.

\section{Muhammad Asad: Tipologi dan Sosio-Politik yang Melingkupinya}

Sudah cukup banyak penelitian yang mengkaji biografi Muhammad Asad atau Leopold Weiss. ${ }^{27}$ Akan tetapi masih cukup sedikit yang membahas latar belakang dari sisi sosio-politik Muhammad Asad dari ketika ia masih di Barat, kemudian melakukan perjalanan ke berbagai belahan dunia Islam (Timur Tengah). Di antaranya adalah di Arab Saudi, dan sampai akhirnya ia menjadi salah satu perancang dasar negara bersama M. Iqbal di Pakistan.

Melihat latar sosio-politik seorang tokoh begitu penting bagi sebuah penelitian, karena dengan demikian kita tidak hanya melihat perubahan (kalau ada) dari seorang tokoh yang diteliti. Karena tidak jarang, sebuah karya tidak pernah lahir dari sebuah ruang yang hampa tanpa konteks yang melingkupinya. Begitu juga dengan Asad, ia menuliskan karya pertamanya yang berkaitan tentang prinsip negara dan pemerintahan Islam atau The Principle of State and Government in Islam setelah bergumul

${ }^{25}$ Topo Santoso, Menggagas Hukum Pidana Islam (Bandung: As-Syamil Press, 2001), 110. Bagi kaum fundamentalis, berbagai macam persoalan di negara-negara Islam diakibatkan karena mereka telah menyimpang dari nilai-nilai Islam yang otentik. Bagi mereka obatnya adalah kembali pada Islam yang sebenarnya (syariat Islam sebagai hukum yang berlaku di bumi), termasuk penghapusan semua hukum dan ketentuan-ketentuan yang diambil dari Barat. Lihat Bernard Lewis, Krisis Islam: Antara Jihad dan Teror yang Keji (terj) (Jakarta: Ina Publikatama, 2004), 127.

${ }^{26}$ Muhammad al-Tahir Ibn al-'Ashur, al-Tahrir wa al-Tanwir (Tunis: Dar al-Sahnun li al-Nashr wa al-Tauzi', 1997, 3, 229. Terkait pandangan Politik Ibnu 'Asyur dalam tafsirnya secara lebih jelas silahkan baca Saifuddin Herlambang, "Politik Identitas dalam Tafsir," Disertasi (Jakarta: Sekolah Pascasarjana UIN Jakarta, 2017).

${ }^{27}$ Leopold Weiss adalah nama asli Muhammad Asad sebelum ia mengganti namanya. Nama Muhammad Asad sendiri ia rubah ketika menyatakan keislamannya di Berlin Islamic Society, Jerman tahun 1926. Penulis belum menemukan alasan khusus kenapa namanya diganti dengan Muhammad Asad. Lihat Kramer, "The Road from Mecca: Muhammad Asad (born Leopold Weiss)" Tel Aviv: The Moshe Dayan Center for Middle Eastern and African Studies, (1999)," 225-247. 
di bumi Pakistan selama kurang lebih enam tahun. Karya yang dikenal sebagai teori pemerintahan Islam ini cukup menjadi gambaran pemikiran Asad tentang negara Islam. Berbagai ayat al-Qur'an pun ia suguhkan dalam bukunya ini. Namun, melihat Asad dari satu karyanya saja tidaklah cukup, apalagi rentang kehidupan Asad cukup lama. Ia hidup hampir satu abad lamanya, yakni mulai tahun 1900-1992. Dari rentang waktu yang lama itulah, tidak jarang para tokoh semisal Kramer berkomentar bahwa ia Asad melewati setiap tren di masa kontemporer. ${ }^{28}$

Supaya lebih mudah melihat gambaran Asad secara utuh, penulis mencoba melakukan tipologi atas pribadi Asad. Pertama, periode kegelisahan, ini terjadi ketika Asad belum mengenal dunia dan agama Islam secara mendalam. Kedua, periode pembentukan diri Asad sebagai tokoh muslim kritis. Ini terjadi setelah Asad mengenal dunia Islam bahkan ikut berkontribusi di dalamnya. Ketiga, periode tenang namun tetap kritis, yakni ketika Asad sudah kembali ke Eropa, khususnya Spanyol.

Untuk tipologi pertama, penulis menilai bahwa dalam periode ini Asad menjadi pemuda yang mencari jati dirinya. Ini terlihat bagaimana sedari kecil ia sudah dihadapkan pada pilihan apakah akan meneruskan tradisi nenek moyangnya untuk menjadi Rabi, seperti kakeknya Benjamin Weiss, ${ }^{29}$ atau malah menentang tradisi itu, seperti ayahnya yang menjadi seorang advokat. Sebagai seorang remaja yang haus akan segala hal, Asad pun sempat hidup dalam ruang keraguan agnostik-seperti para pemuda di masanya. ${ }^{30}$ Keahliannya dalam bidang jurnalistik-setelah sebelumnya "terseok-seok" di Eropa-akhirnya membawanya berkesempatan menjadi koresponden untuk surat kabar Frankfurter Zeitung. ${ }^{31}$ Kesempatan ini menjadi batu loncatan awal bagi Asad untuk mengenal dunia di luar Eropa. Sebagai koresponden, ia mengunjungi berbagai belahan dunia baik Asia maupun Timur Tengah. Ia mengunjungi berbagai negara seperti Mesir, Yordania, Palestina, Syria, Turki dll. ${ }^{32}$ Dalam perjalanannya ini pula, Asad melihat sisi kelam kehidupan di Timur Tengah, khususnya di Palestina. Sebagai orang Yahudi, Asad tidak ragu untuk mengkritik praktik Zionisme itu. Kritikannya ini tertuang dalam karyanya Unromantisches Morgenland; aus dem tagebuch einer reise, terbitan Frankfurt, 1924. Dari karya ini, Asad mendapatkan kepercayaan lebih dari Frankfurter Zeitung untuk mengunjungi berbagai negara lainnya. ${ }^{33}$

Tipologi kedua, periode pembentukan Asad sebagai muslim kritis dan idealis. Ia pun mulai memberikan berkontribusi bagi dunia Islam, khususnya Pakistan. Setelah memeluk agama Islam pada tahun 1926, akses Asad ke dunia muslim semakin terbuka lebar. Terlebih, setahun setelah menyatakan keislamannya, Asad ke Arab Saudi ia menghabiskan waktu selama enam tahun di sana (tahun 1927-1933). Asad pun disambut hangat oleh raja Abdul Aziz ibn Sa'ud (w. 1373 H/1953 M), pendiri

${ }^{28}$ Martin Kramer, "The Road from Mecca: Muhammad Asad (born Leopold Weiss)" Tel Aviv: The Moshe Dayan Center for Middle Eastern and African Studies, (1999), 225-247.

${ }^{29}$ Benjamin Weiss adalah seorang rabbi ortodoks di Czernowitz, Bukovina, Austria. Lihat Abroo Aman, Muhammad Asad: His Contribution to Islamic Learning (Good word books, 2007), 8.

${ }^{30}$ Ismail Ibrahim Nawwab, "A Matter of Love: Muhammad Asad and Islam," Islamic Studies, (2000), 157.

${ }^{31}$ Salah satu surat kabar prestisius di Jerman dan Eropa.

${ }^{32}$ Amir, "Muhammad Asad and International Islamic Colloquium of 1957-58: A Forgotten Chapter from the History of the Punjab University", 2.

${ }^{33}$ Muhammad Asad, Islam at The Crossroads (Gibraltar: Dar al-Andalus, 1982), 10. 
Arab Saudi modern. ${ }^{34}$ Namun, pada tahun 1932, Asad memutuskan untuk pindah dari Arab Saudi ke India. Di antara alasan perpindahannya adalah karena ia kecewa dengan Ibnu Sa'ud. ${ }^{35}$ Di sinilah Asad bertemu dengan seorang penyair, filosof dan pemikir muslim terkemuka Pakistan (setelah memisahkan diri dari India), Muhammad Iqbal (w. 1357 H/1938 M). ${ }^{36}$ Saat Pakistan pisah dari India, bersama dengan Iqbal, Asad adalah salah satu tokoh yang ikut berkontribusi memikirkan landasan negara Republik Islam Pakistan. Terbukti, pada tahun 1947, ia dipercaya sebagai Kepala Departemen Rekonstruksi Islam. Puncaknya ialah ketika Asad ditunjuk menjadi Duta Besar yang berkuasa penuh atas Pakistan di PBB. ${ }^{37}$ Namun, pada tahun 1952, Asad mundur dari jabatannya untuk kemudian menulis autobiografinya, The Road to Mecca. Alasan besar yang menjadi penyebab mundurnya Asad dari Pakistan adalah tidak diterimanya gagasan-gagasannya tentang konsep negara Islam. Sikap Asad yang cukup kecewa dengan Pakistan dijelaskan juga dalam bukunya The Principles of State and Government in Islam. ${ }^{38}$ Di sini terlihat secara sekilas bahwa gagasan Asad tentang negara Islam tidaklah sinkron dengan peta politik Arab Saudi, begitu juga dengan Pakistan. Hal ini lah yang pada akhirnya nanti sedikit banyak berpengaruh pada pola pikir Asad terhadap Islam itu sendiri.

Tipologi ketiga, di periode ini Asad bisa digambarkan sebagai sosok yang lebih tenang namun tetap kritis. Periode ini ditandai dengan kepindahannya ke Eropa, dan sempat berpindah ke Maroko untuk menyelesaikan master piece-nya The Message of The Qur'an pada tahun 1980. Setelah itu, ia kembali ke Barat, kali ini ia menetap di Mijas, Spanyol. ${ }^{39}$ Bisa dikatakan dalam periode ini Asad tidak terlalu dipusingkan dengan dinamika perpolitikan Islam secara langsung. Ia terkesan lebih nyaman dengan dunianya sendiri sebagai penulis ulung dengan menyelesaikan karya tafsirnya dan beberapa karangan lainnya. Meski demikian, Pandangan Asad terhadap perkembangan dunia Islam tidak bisa dikatakan berhenti di sini saja. Ini terlihat ia sempat menulis beberapa karya selama di Barat. Misalnya karya yang berjudul This Law of Ours and Other Essays (1987), ${ }^{40}$ buku ini bisa dikatakan sebagai karya terakhir Asad, yang di dalamnya mencakup beberapa tulisan lamanya di jurnal Arafat, pertama terbit tahun 1946-1947. Di dalamnya, Asad membahas peradaban Barat dan Islam, hukum Islam, peran Ijtihad dan gambaran Asad atas ideologi Pakistan. Di Spanyol lah gambaran Asad yang sudah "matang" sangat terlihat. Karenanya, tafsir The Message sebagai

${ }^{34}$ Ismail Ibrahim Nawwab, "A Matter of Love: Muhammad Asad and Islam,” Islamic Studies, (2000), 160 .

35Sebagaimana ungkapannya "I had for years pinned my hopes on Ibnu Sa'ud as the potential leader of an Islamic revival; and now that these hopes had proved futile, I could see in the entire muslim world only movement that genuinely strove for the fulfillment of the ideal of Islamic society. The Sanusi movement now fighting a last-ditch battle for survival". Lihat Muhammad Asad, The Road to Makkah (New Delhi: Islamic Book Service, 2004), 325.

${ }^{36}$ Muhammad Asad, The Road to Makkah (New Delhi: Islamic Book Service, 2004), 2.

${ }^{37}$ Muhammad Asad, The Road to Makkah (New Delhi: Islamic Book Service, 2004), 2. Lihat juga Idzam Fautanu, "Prinsip-prinsip Ketatanegaraan dalam Islam Perspektif Muhammad Asad," Makalah untuk diskusi dosen UIN Bandung, 2017, 4.

${ }^{38}$ Muhammad Asad, The Principles of State and Government in Islam (Kuala Lumpur: Islamic Book Trust, 2007), xi.

${ }^{39}$ Martin Kramer, "The Road from Mecca: Muhammad Asad (born Leopold Weiss)" Tel Aviv: The Moshe Dayan Center for Middle Eastern and African Studies, (1999), 225-247.

${ }^{40}$ Murad Hofmann, "Europe’s Gift to Islam," Islamic Studies, 39:2 (2000), 238-242. Lihat juga Ismail Ibrahim Nawwab, “A Matter of Love: Muhammad Asad and Islam," Islamic Studies, (2000), 165. 
salah satu karya terakhirnya, patut untuk ditelisik lebih lanjut. Dalam hal ini terkait dengan penafsirannya terhadap ayat-ayat politik.

\section{Tekstulitas dan Kontekstualitas Penafsiran Muhamad Asad terhadap Ayat Politik}

Pembahasan yang telah lalu kiranya sudah cukup untuk memberikan gambaran sekilas tentang dinamika perdebatan penafsiran tentang politik Islam, begitu juga ruang lingkup yang mengiringi kehidupan Muhammad Asad. Dalam pembahasan kali ini, penulis akan memfokuskan pembahasan terkait penafsiran Asad terhadap tiga kasus utama, yakni Demokrasi dan Syura, Pemimpin non-Muslim dan Hukum Jinayah (yang dalam hal ini penulis ambil kasus penerapan hukum potong tangan).

\section{a. Demokrasi dan Syura: Bertentangankah?}

Pembahasan tentang prinsip Syura bisa ditemukan dalam beberapa ayat alQur'an, misalnya (1) surat Ali Imran 3:159 dan (2) al-Syura 42:38. Titik tekan penafsiran Syura atau musyawarah terletak pada ayat Wasyawirbum fil amri dan Wa'amrubum syura bainabum. Penggalan ayat pertama bermakna "Dan bermusyawaratlah dengan mereka dalam urusan itu". Sedangkan penggalan ayat yang kedua bermakna "Sedang urusan mereka (diputuskan) dengan musyawarah antara mereka". ${ }^{41}$

Dua ayat di atas adalah contoh ayat yang pesan utamanya terkait dengan arti penting dari musyawarah atau Syura. Namun di sisi lain, ayat di atas pula yang sampai sekarang masih menjadi sumber perdebatan antara mereka yang menolak demokrasi dan yang menerima demokrasi. Di sini lah letak pentingnya penafsiran Muhammad Asad, sebagai tokoh yang hidupnya mewakili segala generasi kontemporer. ${ }^{42}$ Ia tidak hanya mengerti sejarah politik Islam klasik, namun juga mengetahui perdebatan tentang ideologi yang berkembang di Barat, dan termasuk di antaranya adalah gagasan tentang demokrasi. Lalu seperti apa tafsiran Asad?

Ketika menafsirkaan ayat 159, wa shawirbum fil amr, Asad menjelaskan dalam tafsirnya, "This injunction, implying government by consent and council, must be regarded as one of the fundamental clauses of all Qur'anic legislation relating to statecraft", bahwa ayat ini menyiratkan adanya perintah untuk membentuk suatu pemerintahan yang dibangun atas dasar persetujuan dan adanya dewan di dalamnya. Hal ini menurut Asad adalah salah satu kalimat mendasar di dalam al-Qur'an yang berkaitan dengan kenegaraan. Ia menambahkan, kata ganti "them" dalam ayat wa syawirbum menurutnya kembali pada the believers atau orang beriman, yakni mencakup seluruh komunitas. Sedangkan kata amr di ayat ini-sebagaimana dalam surat asSyura: 38 amrubum syura bainabum ${ }^{43}$ — berarti menyangkut seluruh aspek yang menjadi perhatian publik, termasuk di antaranya administrasi negara. Para ahli (authorities) setuju bahwa meskipun awalnya perintah ini ditujukan pada Nabi, akan tetapi ayat ini mengikat untuk seluruh muslim dan semua waktu. ${ }^{44}$ Atau dalam ungkapan lain, Asad berpegang pada kaidah al-íbrah bi 'umum al-lafdhi la bi khusus al-sabab.

\footnotetext{
${ }^{41}$ Terjemahan yang penulis gunakan adalah Qur'an Kemenag (2016) versi aplikasi 1.3.4.4.

${ }^{42}$ Sebagaimana penuturan Kramer sebelumnya.

${ }^{43}$ Ada beberapa catatan Asad ketika menafsirkan surat al-Syura ini. menurut Asad, "consultation has a double important": (1) umat Islam harus selalu ingat bahwa mereka harus selalu bersatu sebagai sebuah ummah (one single community), (2) bahwa setiap urusan komunal mereka harus diputuskan melalui musyawarah. Lihat Muhammad Asad, The Message of The Qur'an (The Book Foundation, 2008), 951.

${ }^{44}$ Muhammad Asad, The Message of The Qur'an (The Book Foundation, 2008), 125.
} 
Disebutkan dalam tafsirnya bahwa untuk mengetahui lebih jauh tentang hal ini, para pembaca dipersilahkan merujuk pada bukunya State and Government in Islam. Ini secara tidak langsung menunjukkan konsistensi Asad terhadap pemaknaan prinsip Syura. Jadi, meskipun penulisan buku tafsir ini memiliki jarak yang begitu lama, ${ }^{45}$ akan tetapi ia tetap berpegang pada pendapatnya ini. Terlebih telah disebutkan bahwa pemaknaan Asad atas domir "hum" atau "them" dalam ayat di atas diartikan sebagai orang beriman. Persoalannya adalah, apakah pihak-pihak yang diperbolehkan ikut serta dalam musyawarah di pemerintahan adalah eksklusif untuk orang muslim semata? Dalam bukunya State and Government, penulis temukan uraiannya terkait hal ini. Asad menjelaskan bahwa sejarah Islam menyebutkan bahwa istilah dewan musyawarah ini dikenal dengan Majlis Syura, yang mana harus mewakili semua komunitas (whole community) baik laki-laki maupun perempuan. Asad pun menjelaskan bahwa karena syariat tidak mengatur secara jelas terkait metode atau cara pemilihan Majlis Syura ini, maka hal ini diserahkan kepada masyarakat.

Yang menarik di sini adalah bahwa Asad menyinggung istilah self-convessing atau mengkampanyekan diri sendiri demi sebuah jabatan tidaklah dibenarkan. Ia mengutip hadist Nabi yang berbunyi "Janganlah meminta jabatan (Imarah), apabila kamu yang memintanya, maka kamu tidak akan dibantu Allah untuk mendapatkannya. Sebaliknya, apabila hal itu ditawarkan padamu, maka Allah akan membimbingmu." 46 Penulis sedikit menyimpulkan apa yang ingin disampaikan Asad bahwa terkadang ambisi meraih jabatan, baik sebagai anggota dewan atau presiden bila tidak dibarengi oleh kehendak rakyat dan mereka tidak memiliki kapabilitas di dalamnya, maka ia tidak akan menjadi bagian dari pemimpin yang baik. Penukilan Asad terhadap hadis di atas menurut hemat penulis merupakan bentuk kehati-hatian dan antisipasinya bagi masyarakat muslim supaya tidak terlalu terlena dengan jabatan duniawi. Namun kenyataan di dunia muslim sekarang tidaklah seperti apa yang diinginkan Asad. Untuk masa sekarang, hampir tidak mungkin seorang pemimpin—dalam jabatan apapunyang dalam pemilihannya murni dikehendaki oleh rakyat. Yang terjadi sebaliknya, mereka melakukan berbagai upaya (termasuk di dalamnya money politic) dalam mengkampanyekan diri sendiri meski tidak memiliki track record yang mumpuni dalam jabatan-jabatan yang diinginkan.

Hemat penulis, hadist di atas tidak juga harus diartikan bahwa masyarakat muslim dilarang mencalonkan diri dalam pemilihan kepemimpinan, apakah menjadi kepala desa, anggota dewan, bahkan presiden. Akan lebih masuk akal dan diterima di masa sekarang bila pesan yang diambil adalah sebagaimana di atas, bahwa bagi mereka yang memang merasa benar-benar memiliki kemampuan dan memiliki niat baik untuk memperbaiki kekurangan yang masih ada dalam sistem kenegaraan dan lain sebagainya supaya bisa mengisi beberapa jabatan itu. Karena bila tidak demikian, maka mereka yang tidak memiliki kredibilitas lah yang malah akan mengisi posisi tersebut dan akhirnya merugikan masyarakat. Sebagaimana dalam kaidah ushul fiqh

${ }^{45}$ Buku State and Government diterbitkan pertama kali tahun 1961, sedangkan tafsir The Message terbit pada tahun 1980. Konsistensi dari pandangan Asad ini diperkuat dengan salah satu pengantar bukunya State and Government tahun 1980. Di dalamnya Asad menjelaskan bahwa "This was my endeavor twenty years ago. When I wrote The Principle of State and Government in Islam." The Principle of State and Government in Islam, (Kuala Lumpur: Islamic Book Trust, 2007), vii.

${ }^{46}$ Muhammad Asad, The Principle of State and Government in Islam (Kuala Lumpur: Islamic Book Trust, 2007), 45-46. 
dikenal istilah saddudh dhariah atau mencegah terjadinya sesuatu yang dapat merugikan.

Adapun otoritas seorang amir-dalam bahasa Asad-apakah ia harus mengambil pertimbangan dari Majlis Syura atau tidak, dalam hal ini ia jelaskan dalam tafsirnya bahwa meskipun seorang pemimpin boleh mengambil atau menolak masukan dari Majlis Syura, ia tetap tidak boleh sembarangan dalam memutuskan sesuatu. ${ }^{47}$ Sembari menukil sebuah hadist yang diriwayatkan Ali, Asad menjelaskan bahwa Nabi saja dalam beberapa hal meminta pertimbangan kepada para sahabatnya. Penjelasan ini ia nukil dari tafsir Ibnu Katsir.

Lalu, bagaimana Asad menyikapi berbagai istilah atau ideologi yang datang dari Barat? Dalam The Principle of State and Government in Islam, khususnya sub-bab yang ia beri judul "Misapplication of Western Term", Asad mengkritik kalangan muslim modern yang dengan mudahnya mengatakan "Islamic is democratic", atau bahkan mengatakan bahwa tujuan utama Islam adalah terciptanya masyarakat sosialis (establishment of socialist society), ia juga menolak anggapan Barat yang mengatakan bahwa Islam mengajarkan totalitarianism yang akhirnya jatuh pada kediktatoran. Asad melanjutkan, istilah democracy, liberalism, socialism, theocracy dan parliamentary government yang digunakan oleh orang Eropa-Amerika memiliki konteks sejarahnya sendiri. Sebagai contoh, istilah demokrasi di Eropa yang datang dari revolusi Prancis menetapkan bahwa seluruh rakyat memiliki hak sama dalam memilih. Dengan prinsip dasar "one person, one vote". Akan tetapi, lanjut Asad, istilah ini berbeda dengan sejarah Yunani kuno yang memahami demokrasi sebagai "the rule of or by the people", atau demokrasi adalah peraturan dari dan untuk rakyat. Namun mereka (Yunani kuno) memahami arti "people" sebagai orang yang lahir di Yunani, sehingga hal ini tidak berlaku bagi para budak. Lalu apakah Asad lebih menyukai istilah teokrasi? Menurutnya, persoalan ini tidak bisa dijawab dengan mudah apakah "iya" atau "tidak". Asad melanjutkan, apabila yang dimaksudkan adalah sistem sosial yang sistem duniawinya diambil dari teologi masyarakatnya, maka Islam adalah teokrasi. Akan tetapi, bila teokrasi diartikan sebagaimana di zaman pertengahan Eropa, maka jawabannya adalah tidak. ${ }^{48}$

Sebenarnya Asad mengakui bahwa inti demokrasi sesuai dengan makna musyawarah, akan tetapi ia pada akhirnya mengembalikan kekuasaan tertinggi kembali pada Allah. Terlebih, ia lebih menyukai istilah Islami seperti Syura dibandingkan demokrasi hanya karena konsep ini datang dari Barat. ${ }^{49}$ Di sisi lain, bila berbicara dalam konteks sekarang, gagasan Asad yang menolak monarki dan lebih menyukai prinsip Syura ternyata dalam kenyataannya berbeda dengan prinsip monarki yang jelas-jelas dianut oleh beberapa negara Arab seperti Arab Saudi, Uni Emirat Arab, Qatar, Oman, Kuwait, Bahrain, Yorgania, dan Maroko. ${ }^{50}$ Khususnya Arab Saudi — negara yang pernah ia singgahi selama beberapa tahun-dimana

${ }^{47}$ Muhammad Asad, The Message of The Qur'an (The Book Foundation, 2008), 125.

${ }^{48}$ Muhammad Asad, The Principle of State and Government in Islam (Kuala Lumpur: Islamic Book Trust, 2007), 18-21.

${ }^{49}$ Pandangan penulis sesuai dengan analisa Pipip yang mengatakan "He (Asad) is not very accurate when he charges the West with opposition to the Islamic State." Bahwa Asad kurang tepat ketika berpendapat bahwa "Barat" otomatis bertentangan dengan Negara Islam. Lihat Pipip Ahmad Rifai Hasan, "The Political Thought of Muhammad Asad," Tesis, Canada: Montreal, (1998), 164.

${ }^{50}$ https://www.republika.co.id/berita/kolom/resonansi/16/12/18/oidvo1319-mengapademokrasi-gagal-di-arab diakses: 19-06-2019. 
kekuasaan berada penuh di tangan sang raja, lalu pergantian kepemimpinannya menganut model politik dinasti sebagaimana yang dilakukan oleh Umayyah di masa silam dan dilanjutkan beberapa dinasti setelahnya. Sistem seperti inilah yang menurut beberapa kalangan muslim progresif untuk sekarang sudah sangat ketinggalan zaman, karena kemungkinan terjadinya penyalahgunaan kekuasaan dan sifat otoriter dari penguasa menjadi inti utama dari kekurangan sistem ini. Akan tetapi, bila melihat fakta di lapangan, ternyata negara-negara Arab yang mengikuti sistem demokrasi malah di ambang kehancuran, seperti Suriah, Yaman, Libia, dll. Sebaliknya, negaranegara penganut monarki di atas terlihat adem ayem tanpa ada gejolak. Lalu, sebenarnya apa yang salah?

Analisa Bernard Lewis sepertinya dapat menjawab kompleksitas persoalan di atas. Menurutnya, partai-partai dan parlemen-parlemen di negara-negara Timur Tengah yang bergaya Barat hampir sebagian besar berujung pada Tirani yang korup, yang dipertahankan melalui tindakan represif dan indoktrinasi. Satu-satunya model Eropa yang berhasil, dalam arti mencapai tujuannya, adalah kediktatoran dengan satu partai. Partai Ba'th yang berbagai cabangnya menguasai Irak dan Suriah selama puluhan tahun, memiliki karakter terburuk yang diambil dari model Nazi dan Soviet. $^{51}$

Di sisi lain, mungkin penafsiran Asad tentang posisi amir atau presiden menjadi sangat penting untuk dikemukakan lagi. Ia mengingatkan bahwa meskipun seorang amir memiliki wewenang untuk mengambil atau menolak masukan dari Majlis Syura, akan tetapi ia tidak boleh mengambil secara sewenang-wenang dan sembarangan dalam memutuskan sesuatu. ${ }^{52}$ Terlebih, sebagaimana sudah disebutkan di awal bahwa ia sangat hati-hati dalam memberikan pemaknaan akan posisi kepemimpinan (imarab). Jangan sampai posisi kepemimpinan itu membutakan mata manusia terhadap keindahan dunia. Pada intinya, kekuasaan yang tiranik dan korup akan membuat suatu negara mengalami perpecahan dan keruntuhan.

Satu hal yang perlu penulis kritisi dari pandangan Asad dalam pembahasan ini adalah, meskipun ia lebih terbuka akan perubahan model musyawarah-karena Nabi tidak memberikan model khusus yang kaku dan harus diterapkan di sepanjang masa-akan tetapi sikapnya yang terlalu hati-hati terhadap istilah yang datang dari Barat (semisal demokrasi) membuatnya tidak bisa dianggap fleksibel dalam pemberian makna demokrasi. Sebaliknya, ia lebih menyukai penyebutan Syura hanya dengan alasan bahwa Islam mempunyai sumber sendiri, sebuah sikap yang hemat penulis sangat dekat dengan kalangan tekstualis.

\section{b. Non-Muslim Menjadi Pemimpin, Bolehkah?}

Isu tentang pemilihan non-muslim sebagai kepala negara sampai sekarang masih menjadi perdebatan panjang di kalangan ulama'. Implikasi dari pandangan ulama' ini sangat besar, karena ketika masyarakat tidak diberi pemahaman yang jelas akan hal ini, perilaku anarki dan bahkan pengkafiran sesama muslim yang memihak non-muslim-untuk tidak mengatakan berbeda pandangan dan pilihan-menjadi resiko yang siap ditanggung. Contoh kecilnya adalah kasus pemilihan gubernur non-

\footnotetext{
${ }^{51}$ Bernard Lewis, Krisis Islam: Antara Jihad dan Teror yang Keji (Jakarta: Ina Publikatama, 2004),
} 111.

${ }^{52}$ Muhammad Asad, The Principle of State and Government in Islam (Kuala Lumpur: Islamic Book Trust, 2007),125. 
muslim di DKI Jakarta pada September 2016. ${ }^{53}$ Padahal ini masih dalam ranah pemilihan gubernur, apalagi dalam tingkatan presiden sebagai kepala negara.

Dalam konteks yang lebih luas (global), ternyata beberapa negara muslim di dunia memiliki regulasi yang berbeda untuk menghadapi persoalan ini. Mayoritas negara muslim dunia melarang non-muslim menjadi presiden, seperti Tunisia, Algeria, Syria, dll. Sedangkan di beberapa negara mayoritas muslim lain seperti Nigeria, Senegal dan Lebanon nyatanya telah dipimpin oleh non-muslim. Terlebih, dalam kasus di Nigeria sendiri yang berpenduduk 76\% muslim telah dipimpin oleh presiden yang beragama Nasrani, Olusegun Abasanjo. Meskipun demikian, nyatanya Abasanjo mampu meyakinkan hati rakyatnya selama tiga periode. Bila melihat kenyataan di atas, berarti kekhawatiran bahwa sebuah negara akan menjadi "kacau" atau negara akan "dilaknat" Tuhan bila dipimpin non-muslim (doktrin teologis.pen) bukanlah argumentasi yang bisa diterima begitu saja. Apakah Asad termasuk orang yang menolak non-muslim sebagai kepala negara? Mengingat di masa-masa akhir hidupnya, ia juga menjadi warga negara Eropa yang mayoritas penduduknya nonmuslim. Berikut penafsirannya.

Persoalan non-muslim apakah bisa menjadi pemimpin atau tidak bisa tergambar dalam perbedaan penafsiran atas surat Ali Imran 3:28. Penggalan ayat La yattakbidzil mu'minunal kafirina auliya'a min dunil mu'minin. Menurutnya Asad, term "allies" (auliya' jamak dari waliy) dalam konteks ini tidak selalu bermakna aliansi politik. Akan tetapi lebih dari itu, ia juga bermakna aliansi moral. Dalam arti seorang muslim mengikuti gaya hidup orang non-muslim dengan harapan bisa dihormati dan sejajar dengan mereka. ${ }^{54}$ Hal inilah yang dimaksud Asad dengan makna auliya' di atas.

Ketika menafsirkan surat Ali Imran ayat 28, Asad juga mengaitkannya dengan surat al-Nisa': 59. Di situ dijelaskan dengan sangat tegas bahwa ia melarang nonmuslim menduduki jabatan kepala negara. Dalam penjelasan catatan kakinya, ia juga merujuk pada tafsir al-Manar yang menjelaskan bahwa maksud ayat itu adalah mengambil sekutu dalam hal-hal dimana kepentingan non-muslim berbenturan dengan kepentingan orang Islam. ${ }^{55}$ Meski Asad memaknai auliya' bukan sebagai pemimpin, melainkan sekutu, namun pernyataannya tentang makna Ulil Amri dalam surat al-Nisa':59 di atas sudah menjadi bukti bahwa non-muslim baginya tidak diperkenankan menjadi kepala negara. Perbedaannya mungkin terletak pada pendapatnya yang membolehkan para menteri dari non-muslim. Karena dengan berpegang pada idealisme sistem presidensial di mana kepala negara memiliki kekuasaan penuh, maka Asad tidak khawatir akan hal itu (jabatan selain presiden adalah non-muslim.pen). Yang sedikit membingungkan penulis adalah bahwa ia juga berbicara tentang tidak bolehnya terjadi diskriminasi terhadap non-muslim, namun tetap tidak membolehkan mereka menjadi kepala negara. ${ }^{56}$ Pertanyaannya, bukankah dengan adanya pelarangan mereka menjadi kepala negara secara mutlak berakibat pada adanya diskriminasi itu sendiri?

${ }^{53}$ Sahiron Syamsuddin, "Ma'na Cum Maghza Approach to The Qur'an: Interpretation of Q 5:51", Advances in Social Science, Education and Humanities Research (ASSEHR), volume 137, International Conference on Qur'an and Hadith Studies (ICQHS 2017), 131-136.

${ }^{54}$ Muhammad Asad, The Message of The Qur'an (The Book Foundation, 2008), 171.

${ }^{55}$ Muhammad Asad, The Message of The Qur'an (The Book Foundation, 2008), 97.

${ }^{56}$ Muhammad Asad, The Principle of State and Government in Islam (Kuala Lumpur: Islamic Book Trust, 2007), 62-63. 
Argumentasi Asad tentang pelarangan non-muslim menjadi kepala negara juga didasari atas kekhawatirannya akan loyalitas mereka. Sebagaimana ungkapannya, "one cannot escape the fact that no non-Muslim citizen-however great his personal integrity and his loyalty to the state-could, on psychological grounds, ever be supposed to work wholeheartedly for the ideological objectives of lslam; nor, in fairness, could such a demand be made of him." ${ }^{, 57}$ Mengomentari hal ini, Talal Asad ${ }^{58}$ pun akhirnya mengkritisi pandangan ayahnya ini. Menurutnya, ide tentang loyalitas absolut terhadap negara Islam adalah sesuatu yang menimbulkan keraguan (suspect) atau ambigu. Ia bertanya, "Sampai sejauh mana masyarakat non-muslim dalam sebuah negara Islam dapat mengkritik pemerintah yang secara pasti (strictly) bukanlah pemerintahan mereka?" Talal melanjutkan:

"Part of the answer is that the Islamic state has an obligation to protect non-Muslims and allow them total freedom in matters of speech and "belief." But the obligation to protect everyone equally does not entail their right to participate as equals in public life. Thus, when we say that adults have the obligation to protect children this doesn't mean that children have the right to participate equally in adult life. Should non-Muslims in an Islamic state be regarded as children to be protected? Or should they be encouraged to leave their homeland for a state that does not have a Muslim majority? The point is that if the state is not "theirs," non-Muslim citizens cannot really be represented by the Islamic state in which they live-just as the Palestinian citizens of Israel (whether Muslim or Christian) cannot be represented by the Jewish state. So, i respectfully disagree with my father on this matter." 59

Ungkapan Talal di atas pada intinya menjelaskan bahwa ketika memakai logika ayahnya, (begitu juga kebanyakan ulama' muslim.pen), bahwa negara Islam wajib untuk menjaga (protect), memberikan kebebasan (freedom) dalam menjalankan keyakinannya, dll. Akan tetapi kewajiban itu tidak termasuk memberikan mereka hak yang sama di ranah publik, hal ini dianalogikan Talal seperti hubungan orang dewasa dan anak kecil. Talal menjelaskan, "Meski orang dewasa mempunyai kewajiban untuk menjaga anak kecil, ini bukan berarti anak kecil tadi memiliki hak yang sama untuk ikut campur dalam kehidupan orang dewasa tadi." Ia melanjutkan, "Apakah nonmuslim dianggap seperti anak-anak? Atau apakah mereka harus meninggalkan negara yang mayoritas muslim ke negara yang mayoritas non-muslim?” Beberapa argumen inilah yang ia layangkan pada ayahnya sebagai bentuk ketidak setujuan.

Di sisi lain, penulis pun bertanya-tanya, bagaimana bila ketika posisi itu dibalik. Dalam arti, ketika muslim menjadi minoritas, bolehkah ia memilih calon presiden yang kemungkinan besarnya adalah seorang non-muslim? beberapa hal ini yang mungkin tidak diperbincangkan Asad dalam State and Government, The Message of The Qur'an, begitu juga karyanya yang lain. Pendapat seperti inilah yang menurut hemat

${ }^{57}$ Muhammad Asad, The Principle of State and Government in Islam (Kuala Lumpur: Islamic Book Trust, 2007), 40-41.

${ }^{58}$ Talal Asad (1932) adalah anak kandung Muhammad Asad dari istrinya yang bernama Munirah, Talal sekarang menjadi professor dalam bidang antropologi, fokus kajiannya berkaitan dengan kajian Islam dan Timur Tengah. Ia menyelesaikan jenjang magisternya di Edinburg University dan mendapatkan gelar doktornya di Oxford University. Lebih lengkapnya silahkan lihat https://www.gc.cuny.edu/Faculty/Core-Bios/Talal-Asad. Diakses pada tanggal 02-05-2019.

59"Muhammad Asad between Religion and Politics" Review Jurnal Insan ve Toplum (2011), 155-165. Artikel ini ditulis Talal Asad untuk sebuah simposium mengenang ayahnya tahun 11 April 2011 di Riyad. 
penulis tidak bisa memberikan solusi dalam problem kehidupan kontemporer, yakni pluralitas.

Memang, Asad sudah mencoba untuk memikirkan adanya bentuk diskriminasi terhadap non-muslim, sebagaimana ungkapannya:

"This principle would naturally cause no difficulty in countries populated entirely or almost entirely by Muslims (as, for instance, Saudi Arabia and Afghanistan). But in those Muslim countries which contain appreciable non-Muslim minorities-and the majority of Muslim countries fall within this category-the above demand may cause some apprehension inasmuch as it would seem to imply a discrimination between Muslim and non-Muslim citizens. To be sure, this fear of discrimination relates only to the theory and not to the practice of government: for in countries where Muslims form an overwhelming majority (and only these can justifiably be termed "Muslim countries"), the leadership of the state automatically accrues to them. 160

Kalimat di atas dapat dimaknai bahwa memang dalam pandangan Asadperihal pelarangan non-muslim menjadi kepala negara-merupakan hal yang cukup mudah diterapkan bagi negara-negara yang hampir secara keseluruhan penduduknya adalah muslim. Seperti misalnya Saudi Arabia dan Afghanistan. Akan tetapi bagi negara yang sangat menghormati hak minoritas ditakutkan akan terjadi diskriminasi. Anggapan demikian menurut Asad hanya ada dalam teori belaka, karena dalam prakteknya—masih menurut Asad-pemimpin negara yang berpenduduk mayoritas muslim tentu akan memilih muslim. Hemat penulis, bila pun yang akhirnya terpilih menjadi presiden adalah orang Islam, kenapa non-muslim tidak diberi hak untuk mencalonkan diri? bila mengacu pada prinsip demokrasi, bahwa setiap warga negara diberi hak yang sama, otomatis pendapat Asad sudah diskriminatif. Akan lebih baik bila setiap warga negara memang diberi kesempatan yang sama dalam hal pemilihan kepala negara. Dan apabila nantinya para calon yang beragama Islam memang memiliki kredibilitas dan track record yang baik, pasti mereka akan dipilih rakyat. Di sini lah nanti timbul persaingan yang sehat antara setiap warga negara, dan mereka pun akan merasa benar-benar menjadi warga negara. Dalam hal inilah, menurut penulis, Asad gagal dalam memberikan penafsiran kontekstual yang sesuai dengan kebutuhan zaman.

\section{c. Pro Kontra Hukum Potong Tangan}

Pembahasan terakhir yang tak kalah penting dan terkadang sering disalah artikan adalah perihal hukum jinayat (pidana Islam). Bagi kelompok pendukung pendirian negara Islam, penerapan hukum pidana Islam seperti potong tangan merupakan sebuah keharusan. ${ }^{61}$ Bagi mereka, hukum pidana Islam tidaklah seperti hukum modern. Hukum modern merupakan buatan manusia, sedangkan hukum

${ }^{60}$ Muhammad Asad, The Principle of State and Government in Islam (Kuala Lumpur: Islamic Book Trust, 2007), 40.

${ }^{61} \backslash$ An-Na'im menekankan bahwa saat ini tidak ada satu negara pun yang mampu menjalankan seluruh hukum syariat. Sebagaimana ungkapannya "There is no state in the world today, including selfproclaimed so-called Islamic states like Iran, Saudi Arabia and Sudan, that is practically capable of actually living by all the dictates of Shariah, as commonly understood by Muslims everywhere". Lihat Abdullahi Ahmed An-Na'im, "Islam, State and Politics: Separate but Interactive," article published as "Shari'a and Positive Legislation: is an Islamic State Possible or Viable?" In Eugene Cotran and Chibli Mallat, General Editors, Yearbook of Islamic and Middle Eastern Law, Vol. 5 (1998-1999). 
pidana Islam yang membuat adalah Allah. ${ }^{62}$ Padahal bila mengacu pandangan para ulama', mereka berbeda-beda dalam penetapannya. ${ }^{63}$ Di sisi lain, pemahaman yang rigit dan kaku dari kelompok Islamis politis ini bila sudah sampai pada keyakinan penguasa negara, seringkali merampas kebebasan berpendapat bahkan merenggut nyawa mereka yang berbeda pandangan. Contoh yang nyata adalah apa yang menimpa Mahmoud Muhammad Toha. Ia adalah salah satu tokoh muslim di Sudan yang terkena dampak dari penerapan hukum pidana yang sangat kaku pada rezim Numeiri. Karena Toha menolak penerapan hukum pidana Islam, akhirnya ia dihukum mati tahun $1985 .^{64}$

Terkait jenis hukuman dalam persoalan pidana Islam sendiri adakalanya berupa hadd (jamaknya adalah budud) ${ }^{65}$ dan adakalanya berupa $t a^{\prime}$ qir $^{66}{ }^{6}$ Penulis hanya ingin mengkaji hukuman hadd saja, yang terwakili oleh hukum potong tangan. Adapun ayat-ayat hukum potong tangan bisa ditemukan dalam surat al-Maidah 5: 38. Yang kurang lebih artinya sebagai berikut, Adapun laki-laki maupun perempuan yang mencuri, potonglah tangan keduanya (sebagai) balasan atas apa yang mereka kerjakan dan sebagai sikesaan dari Allah. Dan Allah Maha Perkasa lagi Maha Bijaksana.

Dalam tafsir The Message, persoalan terkait hukum pidana semisal potong tangan menjadi pembahasan yang cukup menyita banyak perhatian Asad. Misalnya, dalam kasus hukum potong tangan seperti yang tertera dalam surat al-Maidah 5:38, ia menyatakan bahwa hukuman ekstrim yang dijelaskan dalam al-Qur'an ini hanya dapat dipahami dengan tepat apabila kita mengingat prinsip hukum Islam, yakni tidak ada kewajiban (taklif) yang dibebankan kepada manusia kecuali mereka juga mendapatkan haknya. Demikian juga dalam konteks kewajiban memberikan hukuman (punishment).

Menurut Asad, di antara hak-hak masyarakat muslim (Islamic society)-baik muslim dan non-muslim-adalah adanya hak perlindungan (the right to protection). Hal ini menurut Asad telah banyak dijelaskan dalam ayat al-Qur'an maupun hadist. Di samping itu, keadilan sosial juga harus merata. Asad menekankan bahwa meskipun nilai-nilai spiritual begitu penting dalam kehidupan manusia, akan tetapi hal ini tidak berarti harus melihat bahwa spiritual truths and values atau nilai dan kebenaran spiritual harus dipisahkan dengan faktor fisik dan sosial dalam keberadaan manusia. Maksudnya, Islam mengharapkan dan menginginkan adanya masyarakat yang tidak

62Topo Santoso, Menggagas Hukum Pidana Islam (Bandung: As-Syamil Press, 2001), 110. Bagi kaum fundamentalis, berbagai macam persoalan di negara-negara Islam diakibatkan karena mereka telah menyimpang dari nilai-nilai Islam yang otentik. Bagi mereka obatnya adalah kembali pada Islam yang sebenarnya (syariat Islam sebagai hukum yang berlaku di bumi), termasuk penghapusan semua hukum dan ketentuan-ketentuan yang diambil dari Barat. Lihat Bernard Lewis, Krisis Islam: Antara Jihad dan Teroryang Keji (terj) (Jakarta: Ina Publikatama, 2004), 127.

${ }^{63}$ Shahrur mengkritik keras terhadap jumhur ulama' yang berpegang teguh pada penafsiran secara fisik terhadap kata "tangan" pada ayat di atas. Dengan nada kritis ia menanyakan, "Kenapa pemahaman primitif ini yang dipilih?”. Lihat Muhammad Shahrur, Metodologi Fiqih Islam Kontemporer (terj) (Yogyakarta: Elsaq Press, 2004), cetakan ke-2, 162.

${ }^{64}$ Syukran Kamil, Pemikiran Politik Tematike (Jakarta: Kencana Prenada, 2013), 58.

${ }^{65} \mathrm{Hadd}$ adalah hukum yang ditetapkan secara pasti, yakni memiliki batas dan jumlah tertentu.

${ }^{66}$ Menurut Abu Zahrah, begitu juga menurut ulama' lain, hukum hadd adalah semua jenis hukuman yang telah ditentukan dalam al-Qur'an dan sunnah. Menurut mayoritas ulama', jenis-jenis hukuman dalam hukum pidana Islam adalah (1) qisas dan diyat (2) budud dan (3) ta'zir. Ada juga ulama' yang memasukkan kifarat dalam kategori ini. Lihat Jamal D. Rahman (ed), Wacana Baru Fiqih Sosial: 70 Tabun KH Ali Yafie (Bandung: Mizan, 1997), dalam Ibrahim Hosen "Jenis-jenis Hukuman dalam Hukum Pidana Islam: Reinterpretasi terhadap Pelaksanaan Aturan”, 91-92. 
hanya mementingkan aspek spiritualnya saja, melainkan juga aspek badaniyah dan intelektualnya juga. Oleh karena itu, Asad menjelaskan bahwa untuk menjadi masyarakat (atau negara) yang benar-benar Islami, maka setiap orang harus memiliki unsur kesejahteraan material dan keamanan. Tanpanya, manusia tidak memiliki martabat, kebebasan dan kemajuan spiritual yang nyata. Jika demikian, apabila ada ketimpangan sosial (orang kaya semakin kaya dan orang miskin semakin miskin.pen), maka kemiskinan itu akan menjadi "The most dangerous enemy of spiritual progress, and occasionally drives whole communities away from God-consciousness and into the arms of soul-destroying materialism." ${ }^{97}$ Dalam hal inilah kemudian Asad mengutip sebuah hadist yang terdapat dalam Jami' Saghir-nya Imam al-Suyuti, bahwa "kadang kefakiran membuat orang menjadi kufur".

Asad menambahkan, bila suatu masyarakat sudah terjamin hak sosial dan keamanannya, namun masih ada orang yang mengambil kekayaan orang lain, hukum potong tangan bisa berlaku bagi orang itu. Orang ini disebut Asad sebagai "an attack against the system as a whole". Penting untuk dicatat bahwa menurut Asad absolute interdependence (hubungan yang saling terkait) antara hak masyarakat dan kewajiban harus sesuai (termasuk kewajiban menjalankan hukuman). Oleh karena itu, apabila terdapat masyarakat yang tidak mendapatkan hak-haknya sebagaimana dijelaskan di atas, maka hukuman potong tangan tidak boleh dipaksakan bagi para pelanggar (transgressor). Sebaliknya, cukup diberi hukuman yang lebih ringan (milder forms of administrative punishment). ${ }^{68}$

Dari beberapa penafsiran Asad di atas kita bisa melihat bahwa ia tidak sepakat dengan adanya upaya untuk melegalkan hukum potong tangan secara kaku di manapun dan kapanpun. Akan tetapi ia memberikan syarat bahwa hukuman itu boleh dilakukan ketika masyarakat sudah terjamin hak-haknya, sebagaimana riwayat Umar bin Khattab. Lebih jauh, penafsiran Asad ini sebenarnya masih menyisakan pertanyaan, yakni, apakah ketika para pejabat negara yang melakukan korupsi-yang jelas-jelas dalam jumlah besar dan merugikan rakyat-otomatis hukum potong tangan diberlakukan bagi mereka? Bila analogi yang dipakai Asad seperti itu, sepertinya demikian. Hal ini karena ia tidak menjelaskan lebih jauh siapa yang terkena hukuman ini selain pencuri. Ini tentu berbeda dengan beberapa pandangan tokoh kontemporer seperti Shahrur, Ahmed an-Na'im, Mahmoud Mohammad Taha, begitu juga Quraish Shihab, Ibrahim Hosen, dan lainnya. ${ }^{69}$

Bisa disimpulkan bahwa dalam kasus hukuman potong tangan, Asad sebenarnya lebih memilih untuk bersikap fleksibel dan mencoba untuk mengkontekstualisasikan hukum potong tangan dengan landasan utama riwayat dari sahabat Umar. Namun, sebagaimana analisa singkat penulis di atas, hukum potong

${ }^{67}$ Muhammad Asad, The Message of The Qur'an (The Book Foundation, 2008), 192.

${ }^{68}$ Muhammad Asad, The Message of The Qur'an (The Book Foundation, 2008), 193.

${ }^{69}$ Ibrahim Hosen berpendapat bahwa fungsi utama pensyariatan hukum pidana Islam adalah zawajir dan jawabir sekaligus. Zawajir maksudnya pemindanaan berfungsi untuk menyadarkan perilaku supaya tidak mengulangi lagi. Adapun jawabir adalah bahwa pemindanaan itu berfungsi untuk menyelamatkan pelaku dari siksa di akhirat kelak. Akan tetapi, aspek zawajir-nya lebih menonjol dan dominan. Karena itu, persoalan ini masuk dalam ranah ta'aqquli, bukan ta'abbudi. Lihat Jamal D. Rahman (ed), Wacana Baru Fiqib Sosial: 70 Tahun KH Ali Yafie (Bandung: Mizan, 1997), dalam Ibrahim Hosen "Jenis-jenis Hukuman dalam Hukum Pidana Islam: Reinterpretasi terhadap Pelaksanaan Aturan", 100-103. 
tangan-dalam pandangan Asad-patut untuk diberlakukan bagi mereka yang sudah sudah kaya dan mendapatkan hak-haknya akan tetapi tetap merampas hak publik.

\section{Simpulan}

Setelah membahas berbagai macam pendekatan al-Quran, perdebatan politik Islam dan tipologi pemikiran Asad (yang penulis bagi menjadi tiga), penulis dapat menyimpulkan bahwa penafsiran Asad atas ayat-ayat politik Islam tidak bisa dikategorikan mewakili penafsiran kontekstual. Karena dalam persoalan seperti pengangkatan non-muslim sebagai pemimpin, begitu juga persoalan demokrasi dan syura, penafsiran Asad lebih mendekati kalangan tekstualis. Hal ini sekaligus menjadi catatan bagi kalangan yang menganggap Asad sebagai tokoh kontekstual bahkan liberal-tanpa catatan. Namun demikian, penulis juga harus mengatakan bahwa dalam kasus lain seperti hukuman potong tangan, Asad bisa dimasukkan dalam kalangan kontekstual yang mengatakan bahwa hukum potong tangan tidak bisa diberlakukan seutuhnya tanpa melihat konteks yang melingkupi terjadinya pencurian itu sendiri..

\section{Daftar Pustaka}

'Adzim al-Zarqani, Muhammad Abdul, (2015). Manabil al-Irfan, Kairo: Dar al-Salam, cetakan ke 4.

Abdullah, Amin (2015). Studi Agama: Normativitas atau Historisitas?, Yogyakarta: Pustaka Pelajar.

Ahmed An-Na'im, Abdullahi, (1998). "Islam, State and Politics: Separate but Interactive," article published as "Shari'a and Positive Legislation: is an Islamic State Possible or Viable?" In Eugene Cotran and Chibli Mallat, General Editors, Yearbook of Islamic and Middle Eastern Law, Vol. 5.

Akbarzadeh, Shahram dan Saeed, Abdullah (ed), (2003). Islam and Political Legitimacy. (New York: Routledge Curzon.

al-Farmawi, Abdul Hayy, tt. al-Bidayah fi al-Tafsir al-Maudu'i: Dirasah Manhajizah Maudu'iyah.

Aman, Abroo, (2007). Muhammad Asad: His Contribution to Islamic Learning, Good word books.

Amir, "Muhammad Asad and International Islamic Colloquium of 1957-58: A Forgotten Chapter from the History of the Punjab University".

Asad, Muhammad, (1982). Islam at The Crossroads, Gibraltar: Dar al-Andalus. , (2004). The Road to Makkah, New Delhi: Islamic Book Service. , (2007). The Principles of State and Government in Islam, Kuala Lumpur: Islamic Book Trust.

, (2008). The Message of The Qur'an, The Book Foundation, 2008.

, (2011). "Muhammad Asad between Religion and Politics" Review Jurnal Insan ve Toplum.

Aziz, Abdul, (2011). Chiefdom Madinah: Salab Paham Negara Islam, Jakarta: Pustaka Alvabet.

Budiarjo, Miriam, (2018). Dasar-dasar Ilmu Politik, Jakarta: Gramedia Pustaka, edisi revisi cetakan ke-3.

D. Rahman, Jamal (1997) (ed), Wacana Baru Fiqih Sosial: 70 Tabun KH Ali Yafie, Bandung: Mizan. 
Duderija, Adis, (2011). "Constructing a Religiously Ideal "Believer" and "Woman" in Islam: Neo-traditional Salafi and Progressive Muslims' Method of Interpretation", New York: Palgrave Macmillan.

Effendi, Bahtiar, (2011). Islam dan Negara: Transformasi Gagasan dan Praktik Politik Islam di Indonesia, Jakarta: Democracy Project, edisi Digital.

Fautanu, Idzam, (2017). "Prinsip-prinsip Ketatanegaraan dalam Islam Perspektif Muhammad Asad," Makalah untuk diskusi dosen UIN Bandung.

Gusmian, Islah, (2013). Khazanah Tafsir Indonesia: Dari Hermenentika bingga Ideologi, Yogyakarta: LkiS.

Herlambang, Saifuddin, (2017) "Politik Identitas dalam Tafsir," Disertasi, Jakarta: Sekolah Pascasarjana UIN Jakarta.

Hofmann, Murad, (2000). "Europe's Gift to Islam," Islamic Studies.

https://www.gc.cuny.edu/Faculty/Core-Bios/Talal-Asad. Diakses pada tanggal 0205-2019.

https://www.republika.co.id/berita/kolom/resonansi/16/12/18/oidvo1319mengapa-demokrasi-gagal-di-arab diakses: 19-06-2019.

Ibn al-'Ashur, (1997). Muhammad al-Tahir. al-Tabrir wa al-Tanwir, Tunis: Dar alSahnun li al-Nashr wa al-Tauzi'.

Ibrahim Nawwab, Ismail, (2000). "A Matter of Love: Muhammad Asad and Islam," Islamic Studies.

Kamil, Sukron, (2007). Syari'ab Islam dan HAM, Jakarta: CSRC.

Kamil, Syukran, (2013). Pemikiran Politik Tematik, Jakarta: Kencana Prenada.

Kramer, Martin, (1999). "The Road from Mecca: Muhammad Asad (born Leopold Weiss)" Tel Aviv: The Moshe Dayan Center for Middle Eastern and African Studies".

Lewis, Bernard, (2004). Krisis Islam: Antara Jihad dan Teror yang Keji (terj), Jakarta: Ina Publikatama, 2004.

Merkl, Peter H. (1967). Continuity and Change, New York: Harper and Row.

Puneri Salim, Delmus, (2016). "Politik Islam dalam al-Qur'an: Tafsir Siyasah Surat Ali Imran Ayat 159” Jurnal Aqlam; Journal of Islam and Plurality, Vol. 1, No. 1.

Qattan, Manna' Khalil, tt. Mabahith fi Ulum al-Qur'an, Kairo: Maktabah Wahbah.

Rahman, Fazlur, (1982). Islam and Modernity, Chicago: University of Chicago Press.

Rifai Hasan, Pipip Ahmad, (1998). "The Political Thought of Muhammad Asad," Tesis, Canada: Montreal.

Saeed, Abdullah, (2006). Interpreting the Quran: Towards Comtemporary Approach, New York: Routledge. , (2016). al-Qur'an Abad 21: Tafsir Kontekstual (terj) dari buku Reading the Qur'an in the Twenty First Century, Bandung: Mizan.

Shahrur, Muhammad, (2004). Metodologi Fiqih Islam Kontemporer (terj), Yogyakarta: Elsaq Press, 2004, cetakan ke-2.

Salih, Subhi, (1977). Mabahith fi Ulum al-Qur'an, Beirut: Dar al-'ilmi li al-Malayin.

Santoso, Topo, (2001). Menggagas Hukum Pidana Islam, Bandung: As-Syamil Press.

Shihab, Quraish, (2015). Kaidah Tafsir, Tangerang: Lentera Hati.

Syadzali, Munawwir, (1991). Islam and Governmental System, Jakarta: IndonesianNetherlands Cooperation in Islamic Studies. 
Syamsuddin, Sahiron, (2009). Hermeneutika dan Pengembangan Ulumul Qur'an, Yogyakarta: Pesantren Nawesea Press.

(2017). "Ma'na Cum Maghza Approach to The Qur'an: Interpretation of Q 5:51," Advances in Social Science, Education and Humanities Research (ASSEHR), Vol. 137.

Wahid, Abdurrahman, (2006). Islamku Islam Anda Islam Kita, Jakarta: The Wahid Institute 